\title{
Tax Rebate Policy: Relevansinya dengan Kebijakan Pengelolaan Zakat di Indonesia
}

\author{
Syarif Hidayat Hasibuan \\ Program Pascasarjana Fakultas Hukum Universitas Islam ndonesia \\ Jln. Cik Di Tiro No. 1, Yogyakarta, 55223 \\ syarifhidayatullahhsb@gmail.com
}

\begin{abstract}
The focus of this research is centred around the issue of tax rebate policy (zakat as a tax deduction). The first research problem, how is the legal policy in regards to the management of zakat and taxes from the perspective of the history of legislation in Indonesia? Second, what is the relevance of the tax rebate policy to the zakat management policy in Indonesia? This research is a normative study with juridical and historical approach. The results of the research conclude: First, in every certain period the political and legal characteristics are very progressive, depending on the political conditions and the development of social dynamics at that time. Second, the Malaysian government places zakat as an essential component in order to alleviate poverty and the income of taxpayers is given a $100 \%$ reduction on tax payments from zakat that has been paid, while Indonesia still applies tax deduction (PKP).
\end{abstract}

Key Words: Legal policy; tax rebate policy; zakat management

\begin{abstract}
Abstrak
Fokus penelitian ini berkaitan dengan masalah tax rebate policy (zakat sebagai pengurang pajak). Permasalahan penelitian yang pertama, bagaimana politik hukum tentang pengelolaan zakat dan pajak dari perspektif sejarah perundang-undangan di Indonesia? Kedua, apa relevansi tax rebate policy terhadap kebijakan pengelolaan zakat di Indonesia? Jenis penelitian ini merupakan penelitian normatif dengan pendekatan yuridis dan historis. Hasil penelitian menyimpulkan: Pertama, pada setiap periode tertentu karakteristik politik hukumnya sangat dinamis, tergantung kondisi politik dan perkembangan dinamika sosial yang dihadapi saat itu. Kedua, Pemerintah Malaysia menempatkan zakat sebagai komponen penting dalam rangka mengentaskan kemiskinan dan penghasilan wajib pajak diberikan pengurangan $100 \%$ atas pembayaran pajak dari zakat yang telah dibayarkan, sedangkan di Indonesia masih memakai tax deduction (PKP).
\end{abstract}

Kata-kata Kunci: Legal policy; pengelolaan zakat; tax rebate policy 


\section{Pendahuluan}

Hukum Islam di Indonesia mulai berkembang khususnya dalam bidang Ekonomi Islam hal ini dirasakan dengan lahirnya lembaga-lembaga Ekonomi Islam. Salah satu wujud dari penegakkan Ekonomi Islam (Islamic of law enforcement) dapat dilakukan dengan penegakan hukum di bidang zakat. Penegakan Hukum Zakat merupakan salah satu indikator untuk dapat mewujudkan negara hukum menuju negara kesejahteraan, berkeadilan dan kemakmuran bagi bangsa Indonesia.

Negara Kesatuan Republik Indonesia menjamin kemerdekaan tiap-tiap penduduk untuk beribadah menurut agamanya masing-masing. Pengeluaran zakat merupakan kewajiban umat Islam Indonesia yang mampu dan hasil pengumpulan zakat merupakan sumber dana potensial bagi upaya mewujudkan kesejahteraan masyarakat. Zakat merupakan pranata keagamaan untuk mewujudkan sila ke-lima Pancasila, yaitu keadilan sosial bagi seluruh rakyat Indonesia dengan memperhatikan masyarakat yang kurang mampu. ${ }^{1}$ Upaya penyempurnaan sistem pengelolaan zakat perlu ditingkatkan agar pelaksanaan zakat lebih berhasil dan berdaya guna serta dapat dipertanggungjawabkan.

Negara Republik Indonesia merupakan negara yang berpenduduk dengan mayoritas Islam dan bahkan menjadikan negara satu-satunya muslim terbanyak di dunia dibandingkan dengan negara-negara lainnya. Selaras dengan itu, peran serta masyarakat muslim Indonesia dalam hal ini melalui zakat mempunyai peluang yang besar untuk mewujudkan tujuan negara Republik Indonesia. Sebagaimana yang tertera dalam pembukaan Undang-Undang Dasar Negara Republik Indonesia yang berisikan "memajukan kesejahteraan dan mencerdaskan kehidupan bangsa". ${ }^{2}$ Zakat juga diharapkan menjadi suatu sistem yang secara struktural mampu mengatasi masalah kemiskinan dan mendorong perkembangan perekonomian masyarakat dan perekonomian bangsa.

Bahkan untuk nilai etis dalam aspek zakat semestinya harus dan terus digali serta ditumbuhkembangkan, seperti pengentasan kemiskinan dan pemberdayaan ekonomi, dalam kerangka pemikiran inilah tax rebate policy yang mulai diberlakukan di beberapa negara menjadi fokus perhatian dan dipandang sebagai solusi yang tepat guna meningkatkan pemasukan zakat di Indonesia. Pengkajian nilai etis zakat akan berimplikasi kepada pemikiran tentang bagaimana mengelola sumber-sumber ekonomi secara lebih rasional dan efisien disamping pendapatan pajak yang harus ditingkatkan, supaya dampak sosial yang dicita-

${ }^{1}$ Amiruddin K, "Model-model Pengelolaan Zakat di Dunia Muslim”, AHKAM, Vol. 3, No. 1, 2015: 139 -

${ }^{2}$ Undang-Undang Dasar Republik Indonesia Tahun 1945. 
citakan oleh Islam dan cita-cita negara Indonesia tercapai secara optimal dan integratif.

Legalitas pengelolahan zakat di Indonesia telah memberikan ruang hukum dan memfasilitasi agar ummat Islam bisa menunaikan kewajibannya membayar zakat sekaligus tidak memberatkan double duti (kewajiban ganda) dalam membayar kewajiban pajak. Ditandai dengan lahirnya Undang-Undang No. 38 Tahun 1999 tentang Pengelolaan Zakat dengan 10 bab dan 25 pasal. Seiring dengan perkembangan zaman, pengelolaan zakat menurut Undang-Undang No. 38 Tahun 1999 dianggap tidak relevan lagi, karena banyaknya kelemahan dan kendala yang dihadapi para pengelola zakat dalam menerapkannya. Sehingga pemerintah dianggap perlu membentuk undang-undang yang baru sebagai penyempurna undang-undang sebelumnya, oleh karena itu maka lahirlah Undang-Undang No. 23 Tahun 2011 tentang Pengelolaan Zakat dengan 11 bab dan 47 pasal.

Undang-Undang No. 36 Tahun 2008 tentang Perubahan keempat atas Undang-Undang No. 7 Tahun 1983 tentang Pajak Penghasilan, sebagaimana yang diketahui bahwa legislator telah memasukkan pasal yang mengatur mengenai jaminan pengurangan penghasilan kena pajak bagi tiap pemeluk agama Islam yang membayarkan zakatnya pada badan atau lembaga amil zakat resmi dan terhitung pada periode tahun pembayaran pajak bersangkutan. Pasal 4 ayat (3) menyebutkan yang tidak termasuk sebagai objek pajak adalah di antaranya bantuan sumbangan, termasuk zakat yang diterima oleh badan amil zakat atau lembaga amil zakat yang dibentuk atau disahkan oleh Pemerintah. ${ }^{3}$

Lahirnya Undang-Undang No. 23 Tahun 2011 tentang Pengelolaan Zakat diharapkan mampu untuk meningkatkan efektivitas dan efisiensi pelayanan dalam pengelolaan zakat, serta meningkatkan manfaat zakat untuk mewujudkan kesejahteraan masyarakat dan penanggulangan kemiskinan. Demikian pula harapkan mampu bersinergi dengan Undang-Undang Nomor 36 Tahun 2008 tentang Perpajakan dalam menghimpun pendapatan pajak dan zakat dapat dilakukan secara terintegrasi, masyarkat tidak lagi merasa terbebani dengan dua kewajiban yang sama-sama diatur dalam Undang-Undang.

Melalui Peraturan Direktur Jenderal Pajak Nomor Per-15/Pj/2012 tentang Perubahan Peraturan Direktur Jenderal Pajak Nomor Per-33/Pj/2011 tentang Badan/Lembaga yang dibentuk atau disahkan oleh pemerintah yang ditetapkan sebagai penerima zakat atau sumbangan keagamaan yang sifatnya wajib yang

3 Undang-Undang No. 36 Tahun 2008 tentang Perubahan keempat atas Undang-Undang No. 7 Tahun 1983 tentang Pajak Penghasilan, Pasal 4 ayat 3. 
dapat dikurangkan dari penghasilan bruto telah memberi paradigma terhadap pemahaman tentang pajak penghasilan. Pengurangan dari penghasilan bruto yang dimaksud merupakan pengurangan atas kontribusi wajib kepada Negara yang terutang oleh orang pribadi atau badan atas setiap tambahan kemampuan ekonomis yang diterima wajib pajak dalam negeri atau luar negeri.

Undang-Undang Pengelolaan Zakat sebetulnya telah memberikan penguatan kelembagaan dalam pengelolaan zakat terintegrasi menjadi satu kesatuan terpadu, sehingga Badan Amil Zakat Nasional Provinsi dan Daerah (BAZNAS Provinsi dan Daerah) menjadi satu-satunya lembaga pemegang otoritas zakat dan dibantu oleh Lembaga Amil Zakat (LAZ) dalam pelaksanaan pengumpulan, pendistribusian dan pendayagunaan zakat. Undang-Undang baru ini bermaksud menjadikan lembaga zakat lebih optimal dalam pengumpulan zakat dan pendayagunaan dana zakat. Namun, problematika perolehan dana zakat di Indonesia dinilai masih sangat kecil, jauh dibawah potensi yang harusnya bisa didapatkan, padahal bila upaya pengelolaan dan pengakomodasian ini telah berjalan dengan baik, terjadi integrasi kebijakan hukum zakat sebagai insentif pajak langsung diyakini dapat memberikan suatu efek yang produktif dalam pembangunan nasional.

\section{Rumusan Masalah}

Berdasarkan latar belakang di atas, maka didapatkan rumusan masalah sebagai berikut: Pertama, bagaimana kebijakan regulasi/hukum tentang pengelolaan zakat dan pajak dari perspektif sejarah perundang-undangan di Indonesia? Kedua, apa relevansi tax rebate policy terhadap kebijakan pengelolaan zakat di Indonesia?

\section{Tujuan Penelitian}

Dari perumusan masalah di atas, penelitian ini bertujuan untuk: Pertama, mengetahui kebijakan regulasi tentang pengelolaan zakat dan perpajakan dari perspektif sejarah perundang-undangan. Kedua, mengetahui relevansi tax rebate policy yang diterapkan di Negara Malaysia dengan kebijakan pengelolaan zakat yang berlaku di Indonesia

\section{Metode Penelitian}

Penelitian yang dilakukan adalah jenis penelitian hukum normatif. Penelitian hukum normatif adalah penelitian hukum yang mengkonsepsikan hukum sebagai norma meliputi nilai-nilai, hukum positif dan putusan pengadilan. Cakupan penelitian meliputi penelitian terhadap azas-azas hukum, 
penelitian terhadap sistematika hukum, penelitian terhadap taraf sinkronisasi hukum, yang keseluruhannya tergabung dalam pendekatan konseptual penelitian. ${ }^{4}$ Pendekatan yang digunakan dalam penelitian ini adalah Yuridis Normatif. Maka penelitan ini berbasis pada analisis terhadap norma hukum, baik hukum dalam art law as it is writen in the books and statutes (dalam literatur dan peraturanperundang-undangan). ${ }^{5}$ Data Penelitian berbentuk yuridis normatif, secara umum data yang akan dikumpulkan adalah data yang bersumber dari peraturan perundang-undangan dan bahan-bahan kepustakaan baik buku, jurnal, atau media informasi lain. Data yang diperlukan berupa data sekunder atau data kepustakaan dan dokumen yang berupa bahan-bahan hukum sebagai berikut: Data primer dalam penelitian ini merupakan data atau bahan yang mempunyai kekuatan mengikat secara yuridis. Data skunder diperoleh melalui bahan kepustakaan buku, jurnal penelitian, artikel hukum dan seluruh literatur hukum yang berkaitan dengan masalah tax rebate policy dan apa relevansinya terhadap kebijakan pengelolaan zakat di Indonesia. Teknik Pengumpulan Data dilakukan dengan cara mengumpulkan bahan hukum atau literatur kepustakaan, karena dengannya penulis dapat memperoleh data yang diperlukan dan selanjutnya dianalisa sesuai dengan yang diharapkan.

\section{Hasil Penelitian dan Pembahasan}

\section{Kebijakan Hukum tentang Pengelolaan Zakat dan Pajak dari Perspektif Historis Perundang-undangan di Indonesia}

Menyoal kebijakan hukum atau regulasi tentu berkaitan dengan sistem hukum dan pemerintahan di Indonesia. Sistem pemerintahan Negara Republik Indonesia meyakini bahwa kedaulatan hukum merupakan asas fundamental dalam penyelenggaraan negara, oleh sebab itu maka Indonesia resmi sebagai negara hukum. Konsekuensi logisnya ialah segala tindakan dan kebijakan ketatanegaraan harus dilandasi pada aturan hukum yang diberlakukan. Kondisi dan kebijakan hukum di Indonesia dari masa ke masa terus mengalami perubahan dan perkembangan, tergantung apa dan bagaimana kepentingan penguasa sekaligus kehendak hukum masyarakatnya.

Masa kolonial (pra kemerdekaan) memiliki karakter hukum sendiri begitu pula pasca kemerdekaan, kebijakan hukumnya diwarnai dengan kondisi dan situasi kebangsaan yang dihadapi saat itu. Pra kemerdekaan identik dengan segala sesuatu yang mendukung pengaruh pemerintahan kolonial Belanda,

\footnotetext{
${ }^{4}$ Soerjono Soekanto, Pengantar Penelitian Hukum, Cetakan Ketiga, UI Press, Jakarta, 2010, hlm. 51.

${ }^{5}$ Ronald Dworkin, “Legal Research”, Daedalus, 1973, hlm. 250.
} 
kebijakan hukum, ekonomi dan sebagainya condongnya pro kolonialisme. Berbeda dengan masa kemerdekaan, gelora semangat perjuangan kebangsaan yang kemudian menggerakkan para pendiri bangsa Indonesia untuk merumuskan norma dasar-dasar dalam bernegara, dengan menggali budaya hukum asli bangsa Indonesia sehingga melahirkan Pancasila dan UndangUndang Dasar 1945.

Undang-Undang Dasar 1945 sebagai norma dasar dan sumber hukum positif tertinggi merupakan kristalisasi dari falsafah Pancasila, ia berfungsi menjadi landasan konstitusional dalam membentuk hukum dan penyelenggaraan pemerintahan. Pemerintah harus berupaya menciptakan keadilan sosial, keadilan ekonomi, keadilan hukum, temasuk masalah kesejahteraan masyarakat, diperlukan kebijakan hukum untuk membantu tugas-tugas negara tersbut. Salah satunya dengan mengoptimalkan regulasi pengelolaan zakat, sebab zakat merupakan ajaran yang pokok dalam Islam sejajar dengan perintah shalat, kewajiban bagi setiap muslim dan Islam merupakan agama mayoritas penduduk Indonesia.

Penulis akan menguraikan secara rinci sejauh mana kebijakan hukum tentang periodisasi pengelolaan zakat, titik singgungnya dengan pajak serta politik hukumnya di Indonesia. ${ }^{6}$

\section{Periodisasi Regulasi Zakat di Indonesia}

\section{a. Periode Kolonial}

Zakat dikenal sejak awal masuknya ajaran Islam ke bumi Indonesia, syariat Islam disampaikan kepada masyarakat yang dimotori oleh keberadaan lembaga-lembaga civil society, ditandai dengan menjamurnya pondok pesantren, madrasah, mushala (tempat ibadah) sebagai tempat-tempat untuk mempelajari ajaran agama Islam. Pemerintah Belanda menerbitkan Ordonantie Pemerintah Hindia Belanda No. 6200 Tahun 1905. Peraturan ini menyatakan bahwa Belanda tidak ikut campur lagi dalam pengaturan zakat, akan tetapi zakat dikelola dan berkembang dengan sendirinya di tengah-tengah masyarakat muslim. ${ }^{7}$

\section{b. Periode Orde Lama}

Pada priode orde lama, pemerintah menyadari bahwa pelaksanaan zakat merupakan amanah konstitusional. Sebagaimana yang tercantum dalam UUD 1945, Pasal 29 yang mengatur kebebasan untuk menjalankan syariat agama dan Pasal 34 menyebutkan fakir-miskin dan anak-anak terlantar dipelihara oleh

${ }^{6}$ Masnun Tahir dan Zusiana Elly Triantini, "Integrasi Zakat dan Pajak", $A L-A D A L A H$, Vol. XII, No. $3,2015$.

${ }^{7}$ Ordonantie Pemerintah Hindia Belanda No. 6200 Tahun 1905. 
negara. Atas dasar itu, pemerintah orde lama melalui Menteri Agama, KH. Wahid Hasyim membuat kebijakan dengan menerbitkan surat edaran kementerian agama No. A/VII/17367 Tahun 1951 tentang Pelaksanaan Zakat Fitrah, secara umum Negara sesungguhnya hanya melanjutkan apa yang menjadi ordonansi Belanda dimana Negara tidak ikut mengelola zakat. Namun, pemerintah mengambil inisiatif untuk membantu pada pengawasan zakat dan ini termasuk perkembangan yang berarti terhadap eksistensi pengelolaan zakat di Indonesia. ${ }^{8}$

\section{c. Periode Orde Baru}

Pada priode ini pula pengelolaan zakat di Indonesia semakin berkembang, dibuktikan dengan diberlakukannya berbagai macam regulasi pelaksana setelahnya, diantaranya: penerbitan PMA No. 4 Tahun 1968 tentang pembentukan badan amil zakat dan PMA No. 5 Tahun 1968 tentang Baitul Maal yang digawangi oleh KH. Moh. Dahlan sebagai Menteri Agama ketika itu.

Baitul Maal berfungsi mengumpulkan dana zakat dari ummat muslim, kemudian disetorkan kepada Badan Amil Zakat. Berawal dari PMA diatas dinamika politik pun mulai muncul, kementerian keuangan menolak eksistensi regulasi zakat yang dibuat sebelumnya. Presiden Soeharto mengambil kebijakan yang dipandang sebagai solusi penyelesaian regulasi zakat di Indonesia, yaitu dengan pernyataan Presiden yang menegaskan bahwa pengurusan zakat harus diatur secara sistematis, supaya pendistribusian zakat dapat mendorong agenda pembangunan nasional. ${ }^{9}$

\section{d. Periode Reformasi}

Priode reformasi berawal dari jatuhnya rezim orde baru pada 1998, kondisi politik yang lebih dinamis dan kondisi ekonomi yang sedang krisis disebabkan resesi ekonomi global membuat semakin mulusnya pembentukan regulasi Undang-Undang No. 38 Tahun 1999 tentang Pengelolaan Zakat, diikuti dengan Keputusan Menteri Agama No. 581 Tahun 1999. Pada priode ini pengelolaan zakat mengalami perkembangan yang sangat pesat, terbukti dengan diberikannya kewenangan kepada lembaga-lembaga amil zakat secara luas dan terbuka. Adapun lembaga-lembaga yang disahkan ialah:10 Yayasan

${ }^{8}$ Surat Edaran Kementerian Agama No. A/VII/17367 Tahun 1951 tentang Pelaksanaan Zakat Fitrah

9 Pernyataan Presiden Soharto pada acar Isra' Mi'raj dan Idhul Fitri tahun 1968 yang akhirnya memaksa Menteri Agama mengeluarkan instruksi No. 1 Tahun 1969 tentang Penundaan PMA No. 4 dan No. 5 Tahun 1968.

${ }^{10}$ Keputusan Menteri Agama No. 581 Tahun 1999. 
Baitul Maal Hidayatullah, Yayasan Baitul Maal Muamalat, Yayasan Amanah Takaful, Dompet Dhuafa, LAZIZ Muhammadiyah, LAZ Nahdhotul Ulama, dan lain-lain.

Usaha untuk mengintegrasikan antara pengelolaan zakat dan pajak yang sesuai dengan kehendak mayoritas penduduk Indonesia, sesungguhnya telah baru dimulai ketika diundangkannya Undang-Undang No. 38 Tahun 1999 tentang Pengelolaan Zakat, bisa dilihat pada Pasal 14 ayat (3) yang menyatakan: "Zakat yang telah dibayarkan kepada badan amil zakat atau lembaga amil zakat dikurangkan dari laba atau pendapatan sisa kena pajak dari wajib pajak yang bersangkutan sesuai dengan peraturan perundang-undangan yang berlaku".

\section{e. Priode Demokrasi-Sekarang}

Undang-Undang No. 38 Tahun 1999 hanya berlangsung satu dekade, kemudian direvisi dengan lahirnya Undang-Undang No. 23 Tahun 2011 tentang Zakat, Infaq dan Shadaqah, dalam undang-undang yang baru ini sama sekali tidak menyentuh masalah yang substansial, khususnya mengenai zakat sebagai pengurang penghasilan kena pajak. Undang-Undang No. 23 Tahun 2011 hanya merubah seputar:

a. Masalah kelembagaan pengelola zakat, seperti kebebasan mengelola zakat dalam UU No. 38 Tahun 1999 memberikan kebebasan pada masyarakat, sedangkan UU No. 23 Tahun 2011 hanya masyarakat yang mendapat izin saja dan merupakan organisasi kemasyarakatan Islam.

b. UU yang lama mengatur antara pemerintah dan masyarakat posisinya sama. Namun, di UU yang baru menyebutkan bahwa posisi pemerintah (Baznas) lebih tinggi.

c. Pengaturan sanksi dan pidana, dalam UU No. 38 Tahun 1999 tidak mengatur, sementara UU No. 23 Tahun 2011 mengatur adanya sanksi administratif Pasal 36 bagi yang melanggar Pasal 19, 23, 28 dan 29 dan ketentuan pidana Pasal 39, dan sebagainya. Terbitnya UU yang baru ini menimbulkan kritik keras dari banyak LAZ utamanya masalah izin pendirian dan status LAZ daerah. ${ }^{11}$

\section{Relevansi Tax Rebate Policy dengan Kebijakan Pengelolaan Zakat di Indonesia}

Tax rebate policy merupakan konsep regulasi perundang-undangan tentang zakat yang berlaku di Negara Malaysia, zakat diatur sebagai rebate (credit/pengurang) yang dapat mengurangi pajak langsung, di Indonesia sendiri

${ }^{11}$ Seiring dengan kontroversi UU No. 23/201 langkah judicial rivew (permohonan uji materi) ditempuh oleh LAZ yang tergabung dalam Koalisi Masyarakat Zakat, tepatnya pada 31 oktober Mahkamah Konstitusi menolak sebagian besar gugatan dan mengabulkan gugatan sebagian kecil (sumber: Putusan MK No. 86/PUU$\mathrm{X} / 2012)$ 
pengelolaan zakat masih menggunakan konsep tax deduction, dalam prakteknya zakat masih dipandang sebagai aspek pengurang penghasilan sisa kena pajak. Apa saja kelebihan tax rebate policy serta perbandingannya dengan tax deduction akan dijelaskan di bawah ini.

\section{Hubungan Tax Rebate Policy vs Tax Deduction}

Zakat di Negara Malaysia berhasil mengintegrasikan zakat dan pajak pendapatan, yaitu dengan menerapkan zakat sebagai pengurang pajak langsung dan tidak terbatas, seberapa besarpun zakat yang dibayar akan dikurangkan dari pajak yang terutang, bahkan untuk pajak penghasilan pengurangannya bisa sampai $100 \%$, asalkan syarat zakat dibayar pada taksiran yang sama dan bukti kwitansi dari Jabatan Majelis Agama Islam Negeri di Malaysia terpenuhi.

Sedangkan di Indonesia, baru menggunakan system zakat sebagai Pengurang Penghasilan Kena Pajak (tax deduction), zakat yang dibayarkan tersebut saja yang tidak dikenakan sebagai objek pajak. Namun, setelah zakat dikeluarkan maka sisa penghasilan bruto wajib pajak tetap menjadi objek pajak secara keseluruhan, artinya pengurangan pajak dari aspek zakat tidak begitu signifikan. Seyogianya Indonesia mencontoh Malaysia, zakat yang dibayarkan langsung dikurangkan dari pajak tagihan pajak harusnya dibayarkan.

Negara Malaysia dari aspek pertumbuhan dan pembangunan ekonomi sudah jauh lebih baik, oleh karenanya pemerintah Malaysia bertanggung jawab agar rakyatnya hidup sejahtera. Pemerintah memberikan kebebasan yang begitu luas bagi badan pengelola zakat, pemerintah tidak ikut campur selagi pengalokasian dana zakat digunakan untuk kepentingan kesejahteraan masyarakat, fakir miskin dan sebagainya.

\section{a. Capaian dan Keunggulan Pengelolaan Zakat Sebagai Konskuensi dari tax rebate policy di Malaysia.}

1) Pemerintah Malaysia menempatkan zakat sebagai komponen penting dalam rangka mengentaskan kemiskinan, Baitul Maal pada tiap negara persekutuan bertanggungjawab untuk memberikan bantuan.

2) Zakat dijadikan sebagai instrumen kebijakan fiskal, yang mana penghasilan wajib pajak diberikan pengurangan $100 \%$ atas pembayaran pajak dari zakat yang telah dibayarkan. Dampaknya, program dari dana zakat semakin berkembang, sekarang di Malaysia sudah berdiri Institut Kemahiran dan Universitas Institusi Pengajian Tinggi Awam disingkat IPTA. Tahun 2003 berhasil mendirikan rumah sakit umum (Hospital Pusrawi), dengan konsep integrasi hotel dengan rumah sakit, tentunya dilengkapi dengan fasilitas yang modern. 
3) Badan yang mengurusi indevenden, zakat tidak dikelola secara nasional, akan tetapi zakat dikelola oleh Pusat Pemungutan Pajak (PPZ) sejajar dengan Baitul Maal yang telah lebih dulu ada sebelumnya dibawah pengurusan 14 negara bagian di Malaysia, kalau di Kuala Lumpur ada Majelis Agama Islam Wilayah Persekutuan (MAIWP).

4) Sejak 1978 pemerintah Malaysia telah mengatur pemberian setiap pembayaran zakat individu dapat menjadi tax rebate (pengurang pajak), sementara bagi perusahaan di 1990 pemerintah Malaysia baru memberikan potongan pajak kepada perusahaan yang membayar zakat, dengan nilai potongan masih relatif kecil. Jumlah biaya pajak yang harus dibayar dikurangi dengan pembayaran zakat oleh individu ditahun yang sama, sebelum masuk tahun berikutnya. Agar lebih jelas lihat ilustrasi pada tabel di bawah ini: 12

Tabel 2.

Contoh perhitungan tax rebate atas zakat individu di Malaysia.

\begin{tabular}{ll}
\hline Pajak pendapatan/penghasilan individu & $\operatorname{Rp} 5.000 .000$ \\
Zakat pendapatan & $\operatorname{Rp} 500.000$ \\
Zakat Simpanan & $\operatorname{Rp} 500.000$ \\
Jumlah zakat yang dibayar & $\operatorname{Rp} 1.000 .000$ \\
Jumlah pajak (sisa pajak) yang masih harus dibayar & $\operatorname{Rp} .4 .000 .000$ \\
\hline Sumber data: diolah berdasarkan jurnal diatas. ${ }^{13}$ &
\end{tabular}

\section{b. Realita tax deduction policy vs tax rebate policy sebagai suatu konsep integrasi zakat dan pajak.}

Jika dibandingkan dengan realita tax deduction policy yang digunakan di Indonesia, tidak dapat membuat perolehan dana zakat meningkat secara signifikan sebagaimana Malaysia dengan konsep tax rebatenya, tentunya disebabkan oleh banyak faktor penghambat. Misalnya, tantangan dan masalah yang harus segera diselesaikan baik tantangan yang sifatnya politis maupun dari segi keberanian pemerintah untuk mengevaluasi pelaksanaan efektifitas Undang-undang tentang pengelolaan zakat sekaligus mensinergikan dan mengintegrasikan regulasi pajak dan zakat, dengan menerapkan konsep tax rebate policy yang lebih dulu diterapkan di Malaysia.

Pasalnya potensi zakat di Indonesia mencapai Rp. 217.000.000.000.000,00, dari sumber lain mengatakan potensi zakat Rp. 271.000.000.000.000,00, tetapi dana zakat yang terkumpul menurut data kementerian agama baru sebesar Rp. 6.000.000.000.000,00 pertahun atau hanya 0,2 persen. Wapres Ma'ruf Amin

12 Eko Suprayitno, Radiah Abdul Kader dan Azhar Harun, "Zakat sebagai Pengurang Pajak", Jurnal Penelitian Sosial Keagamaan, Vol. 7, No. 1, 2013, hlm. 19-20.

${ }^{13}$ Ibid. 
pada pertemuan tahunan dan konferensi internasional World Zakat Forum (WZF) Tahun 2019, di Kota Bandung menyebutkan bahwa potensi zakat di Indonesia bisa mencapai Rp. 230.000.000.000.000,00, sementara yang berhasil dikumpulkan hanya sekitar Rp. 8.000.000.000.000,00.

Pertama, tantangan atau hambatan yang sifatnya politis datang dari pemerintah sendiri dalam hal ini ialah Kementerian Keuangan, ada kekhawatiran apabila pajak dikurangi maka akan berdampak pada menurunnya pendapatan negara dari sumber pajak, langkah yang dapat dilakukan adalah dengan meyakinkan Kementerian Keuangan sebagai pihak yang terlibat secara langsung mengurusi pajak dan yang akan mengalami resiko-resiko credit (pengurangan pajak atas zakat yang dibayarkan) berupa perubahan manajemen, mengintensifkan koordinasi dengan badan atau lembaga zakat dan masalah teknis lainnya.

Kedua, ketika diperoleh kesepakatan dengan pihak pemerintah, jalan mulus untuk merevisi undang-undang pengelolaan zakat, UU No. 23 Tahun 2011 pun akan lebih mudah. Integrasi zakat dan pajak dengan konsep tax rebate policy suatu keniscayaan berdampak positif pada pendapatan zakat dan pajak sekaligus. Sebab, baik individu atau badan yang dimiliki muslim secara fsikologis akan merasakan dampaknya berupa ketenangan jiwa dengan menunaikan zakat, disisi lain ia merasakan sebagai warga negara yang taat hukum. Biasanya apabila kesadaran agama seseorang baik justru ia pasti akan taat pada aturan, termasuk aturan tentang pembayaran pajak. Tinggal kerjasama badan pengelola zakat dan pemerintah untuk mensosialisaikan kebijakan tersebut kepada masyarakat. ${ }^{14}$

Sebab-sebab dewasa ini yang membuat kian tidak produktifnya penerimaan zakat di Indonesia, sekalipun sudah menerapakan tax deduction beberapa diantaranya dikarenakan:

1) Sosialisasi yang minim baik dari fiscus maupun amil zakat bahwasanya zakat dapat digunakan sebagai pengurang penghasilan kena pajak.

2) Tidak adanya ketegasan jenis zakat apa saja yang menjadi objek penghasilan tidak kena pajak. Undang-undang pajak menyatakan zakat yang bisa dikurangkan sesuai dengan ketentuan zakat, sementara di Undang-undang

14 Penulis memiliki keyakinan, jika Indonesia menganut tax rebate policy sebagai pedoman untuk mensinergikan zakat dan pajak akan mampu meningkatkan pendapatan zakat secara signifikan, maka dana tersebut dapat dimanfaatkan untuk menyelesaikan persoalan-persoalan sosial, seperti kemiskinan yang pastinya akan meringankan beban pemerintahan itu sendiri. 
zakat mencakup zakat maal seluruhnya, kenyataannya dalam prakteknya hanya zakat profesi yang dapat dikurangi dari penghasilan kena pajak.

3) Manajemen pengelolaan zakat belum dilakukan secara modern sebagaimana yang dilakukan oleh Malaysia, berbeda pula dengan pajak yang sudah dikelola dengan sistem atau dengan cara-cara yang modern dan komprehensif. Kantor pelayanan pajak yang tersebar di seluruh Indonesia, menggunakan teknologi yang memadai, menginventarisir para wajib pajak dengan sistem pelaporan SPT.

4) Tidak diakomodirnya dalam Undang-Undang No. 23 Tahun 2011 tentang Pengelolaan Zakat mengenai aturan sanksi bagi para muzakki yang tidak membayar zakat, sementara baru mengatur sanksi bagi pengelola zakat yang menyelewengkan dana zakat bahkan sampai bisa dipidinakan.

Adapun solusi dan langkah konkrit berdasarkan ketiga problematika diatas guna mendorong pendapatan zakat ialah sebagai berikut:

1) Solusinya bagi fiscus bisa memanfaatkan kesempatan pada saat pelaporan surat pemberitahuan pajak tahunan (SPT) dan bagi amil zakat disaat menyerahkan bukti setor zakat yang diikuti dengan penjelasan kepada muzakki bahwa tanda bukti tersebut dapat digunakan sebagai pengurang PKP.

2) Solusi yang paling memungkinkan dan ideal untuk ditempuh ialah dengan cara mensinergikan undang-undang Zakat dan undang-undang Perpajakan, yaitu dengan merevisi seluruh regulasi yang berkaitan dengannya.

3) Solusinya menempatkan zakat sebagai komponen penting dalam mencapai tujuan negara, sekurang-kurangnya sejajar dengan pajak. Seperti segi manajemen kelembagaannya, yaitu dengan memperjelas posisi Baznas dan LAZ baik yang berkedudukan di pusat maupun yang berada di daerah. Segi status zakat dalam kebijakan fiscal, yaitu dengan memasukkan zakat kedalam Anggaran Pendapatan dan Belanja Negara (APBN), sehingga penerimaan dan pembiayaan dari sumber zakat lebih terukur dan pendistribusiannya lebih merata. Selain itu kepemilikan big data bagi pengelola demikian penting, sebab big data dapat digunakan untuk mengetahui siapa saja mustahik dan siapa saja muzakki.

4) Undang-undang zakat jika direvisi kembali, maka mengenai ketentuan sanksi ini menjadi keharusan yang diakomodir. Membuat tahapan-tahapan pemberian sanksi sesuai dengan tingkat pelanggarannya, sanksi administratif sampai dengan pengenaan sanksi pidana. 
c. Menjawab kritikan sisi negatif dari Tax Rebate Policy dan solusinya.

Ada pendapat yang mengatakan pemanfaatan tax rebate policy berlaku deskriminatif khususnya bagi mereka yang non muslim, maka solusi yang bisa dpakai ialah dengan memberikan hak yang sama, berupa diberikan Lembaga Amal Sosial kepada penganut keyakinan agama diluar agama Islam yang mirip dengan Baznas atau LAZ.

\section{Peran Pemerintah Sebagai Pengelola Zakat dalam Merealisasikan Tax Rebate Policy}

Pemerintah Republik Indonesia memiliki peran sentral untuk menentukan arah kebijakan regulasi zakat dan pajak serta upaya integrasi keduanya sekaligus, sebab pemerintah terikat dengan falsafah Pancasila sebagai ideologi negara dan Konstitusi UUD 1945, sila ke-lima keadilan sosial bagi seluruh rakyat Indonesia, mengandung makna bahwa pemerintah berkewajiban untuk menyelenggarakan segala hal yang berhubungan terhadap realisasi bentuk keadilan sosial yang merata kepada seluruh rakyat Indonesia. Disnilah letak kesesuaian ide yang dibangun oleh negara dengan prinsip-prinsip zakat, diantaranya menumbuhkan kepedulian dan rasa solidaritas untuk membantu masyarakat.

Pasal 34 UUD 1945 menyatakan bahwa fakir miskin dan anak-anak yang terlantar dikelola oleh Negara, dengan dasar ini pula yang mengharuskan negara agar turut terlibat dalam menyukseskan pengelolaan zakat. Sesuai dengan teori residu (fungsi pemerintahan), teori yang dikemukakan oleh Van Vollenhoven tentang fungsi pemerintahan ada empat: fungsi regulasi, fungsi pengawasan, fungsi memerintah dan fungsi mengadili Apabila negara tidak mengatur secara komprehensif, aturan yang jelas khususnya terkait dengan tax rebate policy (zakat sebagai pengurang pajak), relasi zakat dan pajak harus diclearkan. Dampaknya bisa berupa para muzakki enggan atau bahkan menyepelekan perintah zakat, pengelolaan dana zakat tidak dapat optimal, dan tujuan distribusi zakat tidak tercapai secara maksimal kepada para mustahik.

Tax Rebate Policy sangat dimungkinkan untuk diterapkan di Negara Indonesiayang mayoritas rakyatnya adalah muslim, dengan alasan:

Berdasarkan data kependudukan 207 juta jiwa ialah penduduk yang beragama Islam, prosentasenya mencapai $87,18 \%$ dari total penduduk Indonesia yang berjumlah 270 juta jiwa. ${ }^{15}$ Menandakan bahwa subjek pajak terbesar di Indonesia ialah kaum muslimin, pemerintah berupaya untuk meminimalkan kewajiban ganda yang memberatkan tersebut. Solusi mengatasinya, yaitu

15 Sensus Penduduk 2010 Badan Penyelenggara Sensus Indonesia. 
dilakukan upaya titik temu antara pajak dan zakat sehingga kedua kewajiban tersebut dapat dilaksanakan oleh ummat Islam, tanpa memberatkannya. ${ }^{16}$ Pemerintah membuat peraturan yang diharapkan sebagai tawaran solusi untuk menepis kewajiban ganda yang dikenakan kepada ummat Islam, yaitu kewajiban membayar zakat disatu sisi dan disaat yang bersamaan juga wajib membayar pajak kepada negara.

Regulasi pengelolaan zakat yang berlaku sekarang ini, sesungguhnya telah sesuai dengan Ideologi Pancasila dan UUD 1945. Pancasila, khususnya pada sila pertama: Ketuhanan yang Maha Esa dan sila kelima: Keadilan Sosial Bagi Seluruh Rakyat Indonesia. Regulasi zakat sejalan pula dengan UUD 1945, baik dalam pembukaan alinea keempat maupun batang tubuh Pasal 27 ayat (2), Pasal 29 dan 34 yang berbunyi: "fakir miskin dan anak-anak terlantar dipelihara oleh negara".

\section{Penutup}

Berdasarkan hasil analisis, maka penulis membuat kesimpulan sebagai berikut: Pertama, mengenai periodisasi kebijakan hukum pengelolaan zakat dan pajak di Indonesia, terbagi menjadi tiga periode. Periode pra kemerdakaan (kolonial)-pasca kerdekaan (orde baru), periode orde baru-reformasi dan demokrasi-sekarang. Politik hukum pengelolaan zakat dan pajak di Indonesia sangat dinamis, pada setiap periode tergantung karakter pemerintahan yang berkuasa dan kondisi sosial yang berkembang disaat itu. Kedua, relevansi tax rebate policy dengan kebijakan pengelolaan zakat di Indonesia, terdapat dua poin. Hubungan tax rebate policy vs tax deduction sebagai integrasi zakat dan pajak dan Peran Pemerintah Sebagai Pengelola Zakat dalam Merealisasikan Tax Rebate Policy. Berdasarkan uraian-uraian diatas, maka penulis memberikan saran sebagai berikut: Pertama, Periodisasi regulasi zakat pengurang pajak dapat dimanfaatkan sebagai dasar bagi pemerintah untuk terus mengevaluasi, dan memaksimalkan Undang-undang pengelolaan zakat dalam meningkatkan pendapatan zakat sekaligus pajak. Fakta sejarah perundang-undangan tersebut bagi mayoritas muslim penduduk Indonesia seharusnya mampu mendorong kesadaran untuk membayar zakat. Kedua, Konsep tax deduction menurut penulis mendesak untuk dirubah atau direvisi oleh pemerintah selaku pembuat keputusan dan kebijakan hukum dengan menggunakan tax rebate policy, dimana zakat yang dibayarkan dapat mengurangi biaya pajak pribadi sampai 100\%. Solusi yang paling ideal

${ }^{16}$ Dikarenakan zakat merupakan kewajiban bagi tiap muslim yang mukallaf dan pajak adalah kewajiban bagi warga negara, sehingga keduanya harus diperhatikan. Jika ditinjau dari syariat Islam bagi yang enggan berzakat maka orang tersebut mendapatkan dosa bahkan ketika mengingkari kewajibannya seseorang dapat dianggap telah murtad. Sedangkan pajak, para ahli fiqh berbeda pendapat, ada yang mengharamkan, membolehkan dan ada juga yang membolehkan dengan syarat-syarat tertentu. 
untuk ditempuh ialah dengan cara mensinergikan Undang-undang Zakat dan Undang-undang Perpajakan.

\section{Daftar Pustaka}

\section{Buku}

Soekanto, Soerjono, Pengantar Penelitian Hukum, Cetakan Ketiga, UI Press, Jakarta, 2010.

\section{Jurnal}

K., Amiruddin, "Model-model Pengelolaan Zakat di Dunia Muslim", AHKAM, Vol. 3, No. 1, 2015.

Dworkin, Ronald, “Legal Research", Daedalus, 1973.

Tahir, Masnun dan Zusiana Elly Triantini, "Integrasi Zakat dan Pajak", AL'ADALAH, Vol. XII, No. 3, 2015.

Suprayitno, Eko, Radiah Abdul Kader dan Azhar Harun, "Zakat sebagai Pengurang Pajak", Jurnal Penelitian Sosial Keagamaan, Vol. 7, No. 1, 2013.

\section{Peraturan Perundang-undangan}

Undang-Undang Dasar Republik Indonesia Tahun 1945.

Undang-Undang No. 23 Tahun 2011 tentang Zakat, Infaq, Shadaqah.

Undang-Undang No. 36 Tahun 2008 tentang Perubahan keempat atas UndangUndang No. 7 Tahun 1983 tentang Pajak Penghasilan.

Undang-Undang No. 38 Tahun 1999 tentang Pengelolaan Zakat.

Keputusan Menteri Agama No. 581 Tahun 1999.

Surat Edaran Kementerian Agama No. A/VII/17367 Tahun 1951 tentang Pelaksanaan Zakat Fitrah.

Ordonantie Pemerintah Hindia Belanda No. 6200 Tahun 1905.

\section{Putusan Pengadilan}

Putusan MK No. 86/PUU-X/2012. 